Volume 5

Number 3 Student Articles

Article 2

6-1-2019

\title{
Executive Order 13563 Creates Access to Affordable Child Support Orders for Incarcerated Parents
}

Cory Holifield

Texas A\&M University School of Law (Student), cnh010@tamu.edu

Follow this and additional works at: https://scholarship.law.tamu.edu/journal-of-property-law

Part of the Family Law Commons

\section{Recommended Citation}

Cory Holifield, Executive Order 13563 Creates Access to Affordable Child Support Orders for Incarcerated Parents, 5 Tex. A\&M J. Prop. L. 201 (2018).

Available at: https://doi.org/10.37419/JPL.V5.I3.2

This Student Article is brought to you for free and open access by Texas A\&M Law Scholarship. It has been accepted for inclusion in Texas A\&M Journal of Property Law by an authorized editor of Texas A\&M Law Scholarship. For more information, please contact aretteen@law.tamu.edu. 


\title{
Executive Order 13563 Creates Access to Affordable Child Support Orders for InCARCerated Parents
}

\author{
By: Cory Holifield Bennett $\dagger$
}

\begin{abstract}
Former President Barack Obama issued Executive Order 13563: Improving Regulation and Regulatory Review in his last month of presidency, prohibiting States from treating incarceration as voluntary when considering a parent's request for a modification of his or her child support order. Although fully expected to, President Donald Trump has yet to act on the executive order, which right-wing politicians fought vehemently against for two years. This Comment argues that the President should leave the order in action because it will promote payment of child support and relationships between noncustodial parents and their children, as well as help to combat the cycle of incarceration that plagues low-income, noncustodial parents. This Comment also argues that courts should opt to suspend child-support payments for noncustodial parents when they face sentences that will produce significant arrearages by the time the parent is released from incarceration. Finally, the Comment will address how incarceration affects modification of support orders and the cycle of incarceration, who is affected by this cycle, and public views as to President Obama's executive order that attempted to resolve such issues.
\end{abstract}

I. Introduction.............................. 202

II. Civil Contempt \& the Cycle of Incarceration ... 203

A. Contempt \& the Ability to Pay................ 205

1. Establishing the Ability to Pay ............ 206

2. Credibility .......................... 210

3. Protection for Offenders.................... 210

B. Modification of a Child Support Order ........... 211

C. Employment Classification of Incarcerated Parents .. 213

III. Those Affected By the Cycle of IncArceration . 215

A. Indigent Parents .............................. 215

B. African-American Fathers .................... 217

IV. Criticisms of the Executive Order ............. 218

A. Balancing Best Interest of the Child and Father's

Ability to Support......................... 218

B. Tax Payers Picking Up the Slack .............. 220

V. Potential Positive Effects of the Order ........ 221

VI. Conclusion ................................ 222

$\dagger$ Cory Holifield Bennett is a third-year law student at Texas A\&M School of Law anticipating graduation in May 2019. Cory began her work on the Texas A\&M Journal of Property Law in August 2017 and is currently serving as a Senior Staff Member. Prior to attending law school, Cory graduated from Sam Houston State University with a Bachelors of Business Administration in Human Resource Management in 2015.

DOI: https://doi.org/10.37419/JPL.V5.I3.2 


\section{INTRODUCTION}

Family dynamics have shifted as American society has increasingly become more progressive. Long gone are the days of the traditional family structure of husband, wife, and children being the only accepted arrangement. Distinct from the 1950s, when married couple families made up two-thirds of households, more and more households now are opting for non-marital arrangements. ${ }^{1}$ Some believe that the decline in marriage is a result of an increased desire for selfactualization. ${ }^{2}$ Whatever the reason may be, while marriage is on the decline, single parenthood is on the incline. ${ }^{3}$ Unfortunately, single parenthood can mean several things: higher levels of poverty, ${ }^{4}$ more child support orders, and more fathers falling into the trap of massive child support debt.

Throughout the last couple of years of his presidency, President Obama sought to create a more effective, realistic child support system..$^{5}$ Specifically, President Obama wanted to create change for incarcerated parents who faced massive child support arrears upon release from prison. Right-wing politicians criticized President Obama for his position on the matter, and with newly-elected President Trump taking office in January 2017, suspicion arose as to whether the new administration would revoke President Obama's efforts. ${ }^{6}$

On December 20, 2016, President Barack Obama issued an executive order modifying the guidelines for setting child support orders

1. Brigid Schulte, Unlike in the 1950s, There Is No 'Typical' U.S. Family Today, WAsh. Post (Sept. 4, 2014), https://www.washingtonpost.com/news/local/wp/2014/09/ 04/for-the-first-time-since-the-1950s-there-is-no-typical-u-s-family/?utm_term=.81ff71 6 ffe99 [https://perma.cc/2E3B-ZX8M].

2. Alison Sher, Why Aren't Millennials Getting Married?, HUFFPOST (Nov. 11, 2017, 3:17 PM), https://www.huffingtonpost.com/entry/why-arent-millennials-gettingmarried_us_5a075620e4b0ee8ec3694209 [https://perma.cc/S3C4-YEEZ].

3. Schulte, supra note 1.

4. Id.

5. See generally Ayesha Rascoe, Obama Administration Revamps Child Support Rules for Prisoners, Reuters (Dec. 19, 2016, 4:50 PM), https://www.reuters.com/arti cle/us-usa-criminaljustice-childsupport/obama-administration-revamps-child-supportrules-for-prisoners-idUSKBN1482IK [https://perma.cc/5U6D-UQ6Z]; Melissa Boteach \& Rebecca Vallas, 3 Facts You Need to Know About the Obama Administration's Proposed Child Support Rules, CTR. FOR AM. Progress (June 18, 2015, 9:03 AM), https://www.americanprogress.org/issues/poverty/news/2015/06/18/115417/3facts-you-need-to-know-about-the-obama-administrations-proposed-child-supportrules/ [https://perma.cc/AA84-4HMM]; Kelly Cohen, Obama to Help Incarcerated Parents Reduce Child-Support Payments, WAsh. ExAminer (Dec. 21, 2016, 3:26 PM), http://www.washingtonexaminer.com/obama-to-help-incarcerated-parents-reducechild-support-payments/article/2610190 [https://perma.cc/K9QX-3H8N].

6. J.B. Wogan, Trump Leaves Obama's Last-Minute Child Support Rule Alone, Governing (Jan. 31, 2017), http://www.governing.com/topics/health-human-services/ gov-child-support-obama-trump.html [https://perma.cc/BXU8-MZ38]. 
under the Child Support Enforcement Program. ${ }^{7}$ In this final rule, states are prohibited from treating incarceration as "voluntary unemployment' when establishing or modifying [child] support orders." Additionally, noncustodial parents who face incarceration of "more than 180 calendar days" are to be given notice of their right to request a review and adjustment of their current child support orders. ${ }^{9}$ The modifications were made "in order to increase regular, on-time payments to all families, increase the number of noncustodial parents working and supporting their children, and reduce the accumulation of unpaid child support arrears." 10 President Trump has yet to announce any plans to revoke the order.

This Comment will address how "voluntary incarceration" has affected the cycle of incarceration and those falling into the cycle, how the Obama Administration executive order attempts to remedy this, criticisms of the executive order, and the potential positive outcomes that may result from the executive order. This analysis will be accomplished by first looking at civil contempt as it relates to non-payment of child support, the obstacles surrounding modification of support orders, and how an incarcerated parent's employment classification traditionally has determined whether the parent will either be entitled to a modification or faced with massive child support arrearages upon release. Next, the Comment will discuss who would typically be affected by this cycle of incarceration for failure to pay support orders. The Comment will then explore the criticisms and potential positive outcomes for President Obama's executive order that prohibited courts from viewing incarceration as voluntary unemployment.

\section{Civil Contempt \& the Cycle of Incarceration}

In the United States, around 2.2 million people are incarcerated. Of those incarcerated, "about half are parents, and at least [one] in [five] has a child support obligation." It is unknown how many of these parents are incarcerated due to noncompliance of a child support order. But an idea of how many may be gleaned from South Carolina, which reported in 2009 that child support noncompliance made up $13.2 \%$ of jailed inmates. All noncustodial parents may end up imprisoned or jailed one of two ways. ${ }^{11}$ Either the parent committed a criminal of-

7. Flexibility, Efficiency, and Modernization in Child Support Enforcement Programs, 81 Fed. Reg. 93,492 (Dec. 20, 2016) (to be codified at 42 C.F.R. $§ 433 \& 45$ C.F.R. $\$ \S 301-09)$.

8. Id. at 93,495. See also 45 C.F.R. § 302.56(c)(3) (2017).

9. Flexibility, Efficiency, and Modernization in Child Support Enforcement Programs, 81 Fed. Reg. at 93,497. See also 45 C.F.R. § 303.8(b)(7)(ii) (2017).

10. Flexibility, Efficiency, and Modernization in Child Support Enforcement Programs, 81 Fed. Reg. at 93,493.

11. Child Support and Incarceration, Nat'L Conf. St. Legislatures (June 6, 2018), http://www.ncsl.org/research/human-services/child-support-and-incarceration .aspx [https://perma.cc/LC2Q-M2A7]. 
fense separate from anything to do with child support, which typically accompanies a longer period of incarceration, or the parent failed to pay their child support obligation, which resulted in an action for civil contempt of the child support order or criminal nonsupport of the child. ${ }^{12}$ The Child Support Enforcement Act made it possible for states to imprison offenders for the failure to meet their child support obligations. ${ }^{13}$

The Child Support Enforcement Act of 1974 arose from Aid to Families with Dependent Children ("AFDC"), a federal welfare system established in 1935 that provided financial support to families that did not have a wage-earning male. ${ }^{14}$ Originally under the AFDC, mothers were required to meet strict conditions to qualify for aid. ${ }^{15}$ Once qualified, mothers had to follow certain restrictions to keep their aid, including not having any more children and not participating in non-marital cohabitation. ${ }^{16}$ AFDC practices were challenged and defeated in the 1960s. ${ }^{17}$ From there, qualifications for AFDC became more lenient and three times as many families benefitted from the system by $1971 .{ }^{18}$ With the large increase of mothers on welfare, citizen support decreased with the increase in program costs. ${ }^{19}$ This led policymakers to consider the idea of fathers providing support for the families, as opposed to using government money. ${ }^{20}$ The Child Support Enforcement Act of 1974 was thus born in an attempt to accomplish this goal. ${ }^{21}$

The Child Support Enforcement Act started as a way to get noncustodial parents to reimburse the government for the support provided to their families. ${ }^{22}$ The Act required the custodial parent to work with the state to get a child support order and then assign their right to collection of the order to the state. ${ }^{23}$ The Act went through amendments that gave states more responsibilities in collecting support, including strengthening paternity establishment efforts, establishment of guidelines in setting child support orders, and implementing the withholding of fathers' wages to satisfy the support

12. $I d$.

13. Carmen Solomon-Fears, Alison M. Smith \& Carla Berry, Cong. Research Serv., R42389, Child Support Enforcement: Incarceration As the Last Resort Penalty for Nonpayment of Support 3 (2012).

14. Tonya L. Brito, Fathers Behind Bars: Rethinking Child Support Policy Toward Low-Income Noncustodial Fathers and Their Families, 15 J. Gender RACE \& Just. 617, 622-23 (2012).

15. Id. at 623 .

16. $I d$.

17. Id.

18. Id. at 623-24.

19. Id. at 624 .

20. Id.

21. Id.

22. Id. at 625 .

23. Id. 
orders. ${ }^{24}$ Efforts by the state were not enough, however, as a vast majority of fathers were still not paying. ${ }^{25}$ This lack of success brought on the end of AFDC, which the federal government replaced with another federal program titled Temporary Assistance to Needy Families ("TANF") in 1996. TANF focused primarily on promoting mothers to take financial support of their children into their own hands. ${ }^{26}$ TANF still assists families in need today. ${ }^{27}$ Additionally, the government still requires fathers to contribute to the welfare of their children or face the consequences of contempt of court, which may include imprisonment. ${ }^{28}$

The goal of placing someone in contempt of court is to prompt noncustodial parents who have excessive child support arrears to comply with their child support orders. ${ }^{29}$ Civil contempt is not meant to be punishment, ${ }^{30}$ but for many parents, it is. Although "information on the number of people incarcerated for nonpayment of child support is very limited," it is a risk that threatens indigent parents daily. ${ }^{31}$

\section{A. Contempt and the Ability to Pay}

As most would expect, low-income earners make up the largest percentage of those who owe child support arrearages, and many have amassed thousands of dollars of child support debt. ${ }^{32}$ Civil contempt is the court's solution for noncustodial parents who fail to pay child support. Civil contempt is established when the following elements occur: (1) the alleged contemnor had a court order that he did not comply with, and (2) he willfully lacked compliance. ${ }^{33}$ If the alleged contemnor lacks the ability to pay their child support obligations, then they cannot be in contempt of the order. ${ }^{34}$ A parent who faces civil contempt proceedings has the burden of proving that he is unable to pay his ordered child support. ${ }^{35}$ Although it would seem that proving an inability to pay would be fairly easy, it is actually quite complex. ${ }^{36} \mathrm{~A}$

24. $I d$.

25. Id. at 627 .

26. Id. at 629.

27. Temporary Assistance for Needy Families, Off. Fam. Assistance, https://www .acf.hhs.gov/ofa/programs/tanf [https://perma.cc/4VUU-M57H] (last visited Oct. 21, 2018).

28. Solomon-FeArs ET Al., supra note 13, at 5.

29. Child Support \& Incarceration, supra note 11.

30. Id.

31. Matthew Clarke, Poor Parents Fail to Pay Child Support, Go to Jail, Prison LEGAL News (Sept. 2, 2016), https://www.prisonlegalnews.org/news/2016/sep/2/poorparents-fail-pay-child-support-go-jail/ [https://perma.cc/ETD4-FEJF].

32. Elizabeth G. Patterson, Civil Contempt and the Indigent Child Support Obligor: The Silent Return of Debtor's Prison, 18 Cornell J.L. \& Pub. Pol'y 95, 106-07 (2008).

33. $I d$. at $104-05$.

34. Id. at 105 .

35. Id. at 119 .

36. Id. 
contemnor must show that their "employment (or lack thereof), wages, expenses, and assets" all point to an inability to pay. ${ }^{37}$ This is not enough, however, as courts look to several other factors to make this determination, ${ }^{38}$ and even if the contemnor can satisfy every factor, the court's perception of the contemnor's credibility may stand in the way. ${ }^{39}$ In addition to these challenges, the civil contemnor is not afforded the same protections as a criminal defendant, although the contemnor's freedom is similarly at stake. ${ }^{40}$

\section{Establishing the Ability to Pay}

One factor relevant in establishing a contemnor parent's ability to pay is the parent's "good faith responsibility for other obligations." 41 Producing multiple children from multiple relationships, sometimes called "family complexity," is not an uncommon occurrence. ${ }^{42}$ There is no perfect way to handle this situation when setting child support orders for the subsequent children. ${ }^{43}$ Courts must choose between reducing the support provided to the first child and raising concerns that the child is disadvantaged by the parent's subsequent actions or ordering less support for subsequent children than for the first child and raising concerns of fairness. ${ }^{44}$ Regardless of how courts choose to handle this, family complexity has only increased as more people opt for a less traditional way of life, such as cohabitation, having children out of wedlock, and divorcing and remarrying. ${ }^{45}$ Studies suggest that there is a correlation between fathering multiple children to multiple women and delinquency in child support orders; therefore, there is no doubt that family complexity has minimal effect on child support. ${ }^{46}$

Courts also consider whether the contemnor is voluntarily unemployed or underemployed. ${ }^{47}$ Courts will impute income to a noncustodial parent based on the state's child support guidelines if the court

37. $I d$. at 120 .

38. Id. at 120-21.

39. Id. at 121 .

40. Clarke, supra note 31.

41. Patterson, supra note 32, at 120.

42. Daniel R. Meyer, Maria Cancian \& Steven Cook, Multiple-Partner Fertility: Incidence and Implications for Child Support Policy, 79 Soc. SERv. Rev. 577, 577 (2005).

43. See id. at $578-79$.

44. See id.

45. Rebekah Ludwig, Family Complexity and Poverty, InST. FOR Res. ON PovERTY, https://www.irp.wisc.edu/publications/factsheets/pdfs/FactSheet2.pdf [https://per ma.cc/TZQ6-GT8X] (last visited Oct. 21, 2018).

46. Terry-Ann L. Craigie, Child Support Transfers Under Family Complexity 1 (Ctr. For Research on Child Wellbeing, Working Paper No. WP10-15-FF, 2010), https://fragilefamilies.princeton.edu/sites/fragilefamilies/files/wp10-15-ff.pdf [https:// perma.cc/Q5S2-ZW6J].

47. Patterson, supra note 32 , at 120 . 
finds the parent to be voluntarily unemployed or underemployed. ${ }^{48}$ When a noncustodial parent quits his or her job, no matter the parent's reasoning for doing so, it is likely to be considered voluntary. ${ }^{49}$ Even being terminated from a job can be considered voluntary if the termination was the fault of the parent. ${ }^{50}$ If the initial unemployment was involuntary, and the parent remains unemployed and fails to "make sufficient efforts to find employment," the unemployment can be considered voluntary. ${ }^{51}$

The following case, Hunt v. Hunt, shows that not even required religious practices are sufficient reasons for being unemployed or underemployed. In Hunt, the father, Eugene Hunt, challenged a finding that he was in contempt of court when he did not comply with his child support order. ${ }^{52}$ Hunt belonged to a Christian denomination church, Northeast Kingdom Community Church, which required him to give up all worldly possessions and to work only for the church. ${ }^{53}$ In exchange for his work, he was not paid, but rather received free housing and living necessities. ${ }^{54}$ The church prohibited divorce and the support of spouses and children that did not live within the church community. ${ }^{55}$ Hunt had been with the Church for fourteen years, and his wife and children were church members before their split. ${ }^{56}$ When his wife requested support for the children, the trial court determined that Hunt was able to pay support and consequently issued a child support order. ${ }^{57}$ At Hunt's contempt hearing, the court hearing the case, the Essex Family Court, determined that regardless of his religious beliefs Hunt was able to pay support because he was able-bodied and without physical or mental infirmities. ${ }^{58}$ The Court made clear that inability must arise from an actual inability and not religious beliefs that constitute a "conscious, controllable choice." ${ }^{59}$ The Supreme Court of Vermont held that, although this placed a substantial burden on Hunt's right to freely exercise his religion, the support order should be upheld. ${ }^{60}$

Voluntary underemployment is implicated when a custodial parent asks the court to disregard the non-custodial parent's reduction in income based on the fact that the reduction was a result of the noncus-

48. See, e.g., Fla. Stat. Ann. § 61.30(2)(b) (West 2012); Tex. Fam. Code Ann. $\$ 154.066$ (a) (West 2018); VA. Code AnN. § 20-108.1(B)(3) (2013).

49. Patterson, supra note 32, at 113.

50. Id.

51. $I d$.

52. Hunt v. Hunt, 648 A.2d 843, 846 (Vt. 1994).

53. Id.

54. Id.

55. Id.

56. $I d$.

57. Id. at $846-47$.

58. Id. at 847 .

59. $I d$.

60. Id. at 851 . 
todial parent's voluntary action to accept a lower paying job. ${ }^{61}$ Courts may impute income to noncustodial parents that accept a reduction in income equal to their earning capacity, as opposed to their actual income. ${ }^{62}$ Although the purpose of punishing voluntary underemployment is to discourage noncustodial parents from attempting to avoid child support obligations, punishment is often directed at parents who retire, make a career change for reasons of personal satisfaction, seek higher education, or quit their jobs to stay home and care for their children. ${ }^{63}$

The next case serves as an example of underemployment. In Rojas v. Guardado, Juan Jose Rojas, father of the child whose support was in question, appealed from a trial court order that raised his child support obligation based on a determination that he was voluntarily underemployed. ${ }^{64}$ Rojas worked cleaning offices for two healthcare companies three days a week and doing yard work for his "boss" once per week. ${ }^{65} \mathrm{He}$ owned a restaurant that closed a few years prior to the case, but his wife owned a restaurant at the time of trial. ${ }^{66}$ Rojas testified that he was unable to work at his wife's restaurant for several reasons, including he was "unfamiliar with the kitchen," he "[did] not know how to charge customers," he was unable to make pupusas, ${ }^{67}$ and cleaning the restaurant required a mop while his line of work typically involved cleaning with a vacuum. ${ }^{68} \mathrm{He}$ also claimed that he sometimes has to wait for calls from his boss, and therefore, he cannot work during the restaurant's business hours. ${ }^{69}$ The appeals court upheld the trial court's decision that Rojas was underemployed on the basis that he only worked a few days a week, he did not make efforts to learn how to work in his wife's restaurant, and he did not get paid to wait for calls from his boss when he is not at work. ${ }^{70}$

In Ledbetter v. Godsey, a noncustodial mother originally sought a reduction in her child support order after termination from her employment. ${ }^{71}$ A few months later, the mother enrolled as a full-time student in the hopes that she would be accepted into a nursing pro-

61. Lewis Becker, Spousal and Child Support and the "Voluntary Reduction of Income” Doctrine, 29 Conn. L. REv. 647, 654 (1997).

62. Id. at 647.

63. Id. at $647-48$.

64. Rojas v. Guardado, No. 01-13-00049-CV, 2014 Tex. App. LEXIS 11765, at *6

(Houston [1st Dist.] Oct. 28, 2014, no pet.).

65. Id. at $* 1-2$.

66. Id. at $* 2$.

67. Pupusas are a Salvadorean dish of thick corn tortillas stuffed with savory fillings such as cheese, beans, meats, and vegetables.

68. Rojas, 2014 Tex. App. LEXIS 11765, at*3-4.

69. Id. at $* 4$.

70. $I d$. at $* 12-13$.

71. State ex rel. Ledbetter v. Godsey, No. M1998-00958-COA-R3-CV, 2000 Tenn. App. LEXIS 406, at *2-3 (Tenn. Ct. App. 2000). 
gram. ${ }^{72}$ During her time as a student, the mother worked on-and-off part-time jobs. ${ }^{73}$ At the time of the order, where the court determined that she was able to pay $\$ 325$ per month in child support and $\$ 150$ per month towards her arrearages, the mother earned about $\$ 950$ per month and was still a student. ${ }^{74}$ On appeal, the court determined that although the mother's initial termination from employment was involuntary, ${ }^{75}$ her subsequent decision to attend school in lieu of finding equal employment was sufficient to constitute voluntary underemployment. ${ }^{76}$ In this decision, the court reiterated prior decisions' reasoning that "even where the choice of unemployment or underemployment is made for a reason other than avoidance or lessening of a support obligation, our courts are reluctant to allow parents to make such a voluntary choice when the effect is an inability to meet previously imposed obligations to support one's children."77

Courts may also consider whether the contemnor has the ability to borrow the funds necessary to pay the child support. ${ }^{78}$ In Texas, for example, the inability to borrow funds is a requirement for a prima facie case of inability to pay. According to the Texas Family Code, an obligor must prove that they "attempted unsuccessfully to borrow the funds needed" to pay their child support and "knew of no source from which the money could have been borrowed or legally obtained" in order to successfully challenge their ability to pay in a contempt hearing. ${ }^{79}$ In re Nash provides an example of how the Texas courts impose this element. ${ }^{80}$

In Nash, father Curtis Nash challenged his incarceration for civil contempt, claiming an inability to pay. ${ }^{81}$ After the court found Nash in contempt for failure to pay child support, he was ordered to serve indefinitely in the county jail until he was able to pay off the $\$ 45,017.82$ he owed in child support plus attorney fees and court costs. ${ }^{82}$ Nash's testimony indicated that he was on work release through the county jail, working as a restaurant cook and making only six dollars-per-hour. ${ }^{83} \mathrm{He}$ consistently worked between eight and twelve hours per day. ${ }^{84}$ Nash did not have a bank account, cash, or

72. Id. at $* 3$.

73. Id.

74. Id. at *6-7.

75. $I d$. at $* 20$.

76. $I d$. at $* 31$.

77. Id. at $* 29-30$.

78. Patterson, supra note 32, at 120-21.

79. Tex. Fam. Code Ann. § 157.008(c)(3)-(4) (West 1995).

80. In re Nash, No. 07-08-0181-CV, 2008 Tex. App. LEXIS 4866, at *4-5 (Tex. App.-Amarillo 2008).

81. Id. at $* 2-3$.

82. Id. at $* 1-2$.

83. Id. at $* 3$.

84. Id. 
any property that he could sell. ${ }^{85}$ Additionally, he testified that "he [knew] of no one that he [could] borrow the money from." 86 The court, however, was not convinced of Nash's inability to pay, and they found that he failed to meet his burden of proof because "the evidence [failed] to show that Nash ... attempted to borrow the funds to pay the amount owed." 87 The court determined that Nash simply concluded he could not borrow the funds from anyone without actually attempting to borrow, so they denied his petition and sent him back to the county jail until he could come up with over $\$ 40,000$ to pay off his child support arrears. ${ }^{88}$ This case also serves as a great example of a contemnor's testimony not being sufficient to establish the factors or elements to prove their inability to pay.

\section{Credibility}

Testimony as to the factors by the contemnor establishing the inability to pay may not be enough or may be seen as lacking credibility, and a court will require the contemnor to present documentation supporting his testimony. ${ }^{89}$ Unfortunately, most indigent, noncustodial parents generally do not keep up with such documentation due to instability in work and home lives. ${ }^{90}$ Additionally, a judge may use wide discretion in determining credibility; although there are often cultural and economic factors that create distance between the judge and the parent. ${ }^{91}$ Unfortunately, if the judge awards no credibility to their testimony, these parents have no proof of an inability to pay.

\section{Protection for Offenders}

In cases of civil contempt, the court affords the offenders fewer protections than criminal defendants, even though imprisonment is a possible punishment for the civil contemnor. ${ }^{92}$ Because compliance with the support order, or in other words, paying what is owed, will release the parent, providing fewer protections to such offenders is thought to be justified. ${ }^{93}$ Therefore, a parent facing civil contempt receives minimal due process protections, and the judge determines the parent's freedom. ${ }^{94}$

An important protection that those facing civil contempt are not provided, as opposed to those facing criminal charges, is the presump-

\footnotetext{
85. $I d$.

86. Id.

87. $I d$. at $* 4$.

88. Id. at $* 4-5$.

89. Patterson, supra note 32, at 121.

90. Id.

91. Patterson, supra note 32, at 136-37.

92. Id. at $102-03$.

93. $I d$. at 103 .

94. Id.
} 
tion of innocence. ${ }^{95}$ This means that the parent brought in for contempt has the burden of proving they are unable to pay child support to avoid jail time. ${ }^{96}$ This burden on the parent may seem like a logical prerequisite initially - if a parent is not paying child support, it should be that parent's responsibility to provide a valid reason for the nonpayment. As discussed previously, mere testimony is not always enough. ${ }^{97}$ The parent will often need to provide supporting documentation proving that the parent's income (or lack thereof) and that the parent attempted to secure employment. ${ }^{98}$ Providing this documentation can be especially challenging for someone who is poor and lacks knowledge of our justice system, as they likely will not know what is expected of them in such a hearing and cannot afford an attorney to represent their interests. ${ }^{99}$ Moreover, because civil contemnors are given fewer constitutional protections, they typically do not have the right to an attorney, meaning that the court will not provide them with one if they cannot afford representation. ${ }^{100}$

A possible solution to avoid the hurdles of civil contempt for failure to pay child support-proving inability to pay, credibility of a defendant's testimony, and the lack of constitutional protections-is for the noncustodial parent to seek a modification to their child support order. Child support modifications, however, come with significant hurdles as well.

\section{B. Modification of a Child Support Order}

A parent may seek a modification to their child support order when unable to pay, prevent the accumulation of child support debt, and avoid falling into a cycle of continuous imprisonment for their inability to pay down the large debt. Custodial and noncustodial parents alike may seek modification of a current child support order when there is a change of circumstances, such as becoming indigent or incarcerated. ${ }^{101}$ Courts look to several factors to determine whether a modification is appropriate, including a decrease in income by either parent, an increased need by the minor in question, the noncustodial parent's responsibilities to subsequent children, and an increase of

95. Clarke, supra note 31.

96. Id.

97. Patterson, supra note 32 , at 121.

98. Clarke, supra note 31.

99. Id.

100. Id. See generally Turner v. Rodgers, 564 U.S. 431 (2011) (holding that the Due Process Clause may require the state to provide counsel in a civil contempt hearing depending on the defendant's ability to pay, the balance of representation, and a set of "substitute procedural safeguards").

101. Debrina Washington, Requesting Child Support Modification in Court, BALANCE (May 31, 2018) https://www.thebalance.com/requesting-child-support-modifica tion-in-court-2997619 [https://perma.cc/T49C-63DR]. 
money available to the noncustodial parent. ${ }^{102}$ Such modifications may be either temporary or permanent, depending on the needs of the child. $^{103}$

A noncustodial parent seeking modification of his child support order has a few barriers to overcome to accomplish this. ${ }^{104}$ One such barrier is the requirements that a parent must meet to even be considered for a modification. ${ }^{105}$ Under federal law, child support orders are required to be reviewed, and possibly adjusted, every three years upon request by a parent. ${ }^{106}$ However, this three-year interval is unrealistic for many if their income suddenly changes. The solution to this is that a noncustodial parent may, at any time, request a modification of his child support order if he can show that he experienced a change in circumstances regarding his ability to pay. ${ }^{107}$ State requirements for what constitutes a change in circumstances vary, but all states require that the change be substantial. ${ }^{108}$ Other common requirements are that the change be an unforeseeable occurrence when the original order was set and that the change was involuntary. ${ }^{109}$

Another barrier is that the legal system disfavors downward adjustments to child support awards. ${ }^{110}$ Administratively, this disfavor may be displayed in policies surrounding downward modifications, including: the treatment of parents seeking such a modification, requiring that their payments be current to receive a review, or simply barring downward modifications. ${ }^{111}$ Judges may also stand in the way of a noncustodial parent receiving a downward modification. ${ }^{112}$ When a parent can prove a change of circumstances, a judge may still impute income to that parent by finding that the change was voluntary. ${ }^{113}$

The final barrier is access to the modification process. ${ }^{114}$ Lacking knowledge of one's legal rights or how to access the system can make the modification process daunting. ${ }^{115}$ Specifically, for an incarcerated parent, lack of knowledge has contributed to the accumulation of child support arrears. ${ }^{116}$ Incarcerated parents are often not informed that child support orders may be modified, causing child support debt

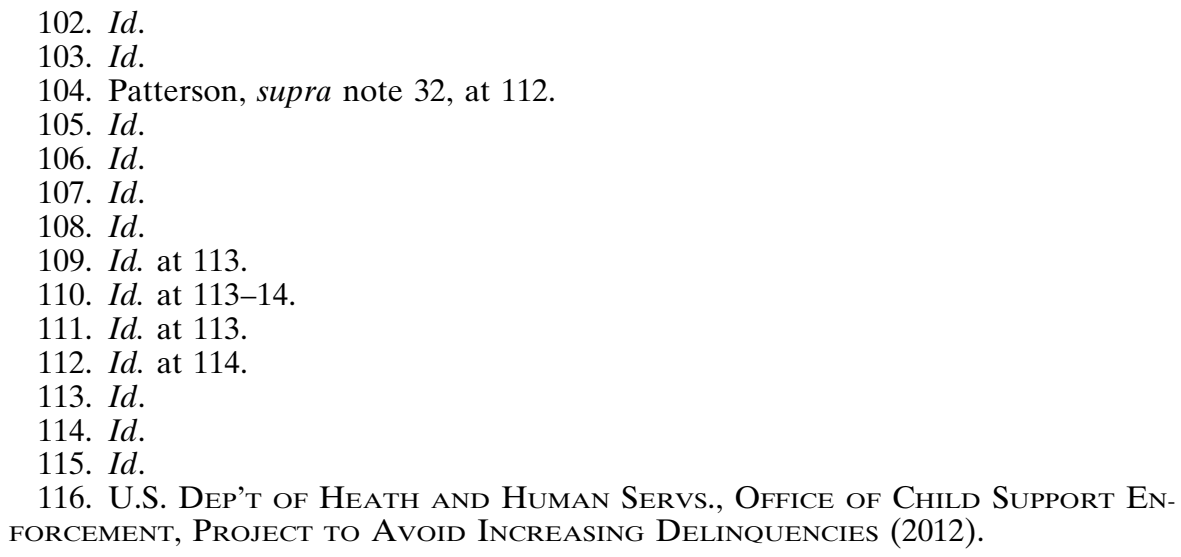


to accumulate. ${ }^{117}$ Additionally, low-income parents seeking a downward modification typically do not have the financial ability to hire an attorney to guide them through the process. ${ }^{118}$

For any formerly incarcerated parents, the crux of having a child support order modified is how the court perceives the parent's change in circumstances, specifically whether their incarceration is considered voluntary or involuntary.

\section{Employment Classification of Incarcerated Parents}

State courts look to three factors when evaluating a request to modify child support for an incarcerated parent: (1) whether the parent has experienced a change in circumstances that would affect his or her ability to pay, (2) whether the parent has assets that could satisfy the child support order, and (3) whether the parent's incarceration was voluntary. ${ }^{119}$ This initial evaluation is very important when considering an incarcerated parent's modification request, as federal law does not allow retroactive forgiveness of support that is already owed. ${ }^{120}$ Therefore, the accumulated debt is abated only by the parent paying it down.

Before the modification to the federal guidelines for setting child support orders, state courts would decide whether incarceration was voluntary or involuntary unemployment and to determine how much weight would be given to the incarceration when reviewing a request for modification of child support. ${ }^{121}$ Some courts considered incarceration as voluntary unemployment, believing the incarceration resulted from a voluntary illegal action. ${ }^{122}$ Those courts viewed incarceration as similar to the parent quitting his job. ${ }^{123}$ Other courts held that incarceration was involuntary as long as it was "not due to some act that was intended to relieve the defendant from child support obligations," 124 such as failure to pay child support. ${ }^{125}$ These courts equated the incarceration with a disability that prevented the parent from working. ${ }^{126}$

The split among jurisdictions led to very different outcomes for parents across the nation looking to reduce their child support payments

117. Id. at 1.

118. Patterson, supra note 32 , at 114 .

119. Karen Rothschild Cavanaugh \& Daniel Pollack, Child Support Obligations of Incarcerated Parents, 7 Cornell J.L. \& PuB. Pol'y 531, 534 (1998).

120. Jessica Pearson, Building Debt While Doing Time: Child Support and Incarceration, 43 Judges' J. 5 (2004).

121. Cavanaugh \& Pollack, supra note 119, at 534.

122. Id. at 544-45.

123. Id. at 546 .

124. Id. at 545 .

125. Id. at 547.

126. Id. at 546 . 
while imprisoned. ${ }^{127}$ In Niblett $v$. Niblett, a Virginia child-support case, the trial court determined that the father's incarceration constituted voluntary unemployment, but it declined to impute income to the father as it did not know what his earning capacity would be after his release. ${ }^{128}$ The appeals court reversed the decision not to impute income and based the father's income on his previous employment. ${ }^{129}$ The court reasoned that income should be imputed based on the earning capacity of the father before his voluntary unemployment, even though this was prior to his two felony convictions. ${ }^{130}$ Alternatively, in Wills v. Jones, a Maryland case where an incarcerated father requested modification of his child support order for the duration of his ten-year prison sentence, the parent received a much different outcome. ${ }^{131}$ The Maryland Court stated that equating incarceration to voluntary unemployment based on the father's voluntary and criminal choices would "[stretch] the meaning of the word [voluntary] beyond its acceptable boundaries." 132 The Court further reasoned that a parent would only be considered voluntarily impoverished (Maryland's version of voluntary unemployment ${ }^{133}$ ) due to his incarceration if "the crime leading to incarceration was committed with the intention of becoming incarcerated" in order to avoid child support obligations. ${ }^{134}$

States that opted to consider a parent's incarceration voluntary, and thereby precluded the parent from receiving a downward modification to their child support order, essentially set the parent up for failure once released from prison. Child support arrears for those incarcerated would continue to accumulate as the parent was locked up, as well as interest on the debt and late-penalty charges. ${ }^{135}$ So naturally, the longer a parent was incarcerated, the larger his debt was upon release. ${ }^{136}$ Once released, the parent must then face the reality that he has no saved money, no income, no recent work experience, and "a host of barriers to employment," ${ }^{137}$ which make paying down his child support arrears cumbersome at best. If the parent does find employment, $65 \%$ of their pay may be automatically garnished from their

127. Id. at $545-46$.

128. Niblett v. Niblett, 779 S.E.2d 839, 842 (Va. Ct. App. 2015).

129. Id. at 846 .

130. Id. at $846-47$.

131. Wills v. Jones, 667 A.2d 331, 333 (Md. 1995).

132. Id. at 339 .

133. Id. at 337 (explaining that the Maryland Legislature replaced "unemployment or underemployment" with the term "voluntary impoverished" in their child support guidelines).

134. Id. at 339.

135. Pearson, supra note 120 , at 7.

136. A Massachusetts study revealed that a parent with an average child support arrearage, $\$ 10,543$, at the time of incarceration would ultimately accumulate an added $\$ 20,461$ while serving time. Id.

137. Id. at 8 . 
wages, ${ }^{138}$ leaving them little to maintain their own needs. Some states require child support payment as a condition for parole, so the parent who struggles to pay once out of prison may then be incarcerated for violation of their parole. ${ }^{139}$ Not only does this create a vicious cycle for these noncustodial parents, but it may also discourage them from maintaining a connection to their children and from seeking legitimate employment. ${ }^{140}$

Presently, states may no longer consider incarcerated parents voluntarily unemployed, as a consequence of President Obama's executive order regarding the Child Support Enforcement Act. ${ }^{141}$ However, a court still may look at the other two factors to determine whether modification is appropriate. ${ }^{142}$ A court may still determine that, although incarceration is not voluntary, the change in circumstances due to the incarceration is not sufficient for modification. ${ }^{143}$ Most courts require that the change in circumstances carry with it a "degree of permanence." 144 There is no agreement, however, as to what permanence entails. ${ }^{145}$ Courts may also look to the incarcerated parent's assets to determine whether to grant a modification, and the term "assets" varies from one court to the next. ${ }^{146}$

Nonetheless, the executive order is a step in the right direction to creating a more realistic and effective child support enforcement system and to helping those who are incarcerated with reentry upon their release.

\section{Those Affected By the Cycle of Incarceration}

The cycle of incarceration stemming from the inability to pay child support upon release from prison is harmful to all incarcerated and indigent parents, but it appears to target certain types of people. ${ }^{147}$ Specifically, the cycle is more likely to affect impoverished, low-income, and African American parents. ${ }^{148}$

\section{A. Indigent Parents}

Under the Child Support Enforcement Act of 1984 and the Family Support Act of 1988, all noncustodial parents have an equal responsibility to financially support their children. ${ }^{149}$ Low-income parents hold

\footnotetext{
138. Id.

139. Id.

140. $I d$.

141. 45 CFR $\S 302.56(c)(3)$ (2017).

142. Cavanaugh \& Pollack, supra note 119, at 534.

143. Id. at 535 .

144. Id. at 537.

145. Id.

146. Id. at 539.

147. Solomon-Fears, supra note 13 , at 15.

148. Id.

149. Brito, supra note 14, at 635.
} 
no exception to this responsibility. ${ }^{150}$ Under these Acts, states must formulate mandatory guidelines for establishment of child support. ${ }^{151}$ These guidelines, however, operate merely as a rebuttable presumption of what a noncustodial parent should pay, and a judge may depart from the guidelines when necessary. ${ }^{152}$

In regards to low-income noncustodial parents, state guidelines vary. ${ }^{153}$ Setting a presumptive, rebuttable award of a specified amount, such as $\$ 50,{ }^{154}$ leaving the award amount to judicial discretion, ${ }^{155}$ establishing child support schedules, ${ }^{156}$ and setting minimum order amounts ranging from $\$ 20-50$ are all ways that states seek to oblige low-income parents. ${ }^{157}$ Presenting options for noncustodial parents with low incomes reinforces the public policy position that parents of all incomes should be held responsible for supporting their children. ${ }^{158}$ However, for those parents with no income, even the minimum award amount is a heavy burden to bear. ${ }^{159}$ This is especially true for incarcerated parents, who lack opportunities to earn money. ${ }^{160}$

The methods of enforcing compliance with a child support order for impoverished or financially stable parents who are not the same, yet they yield entirely different results. ${ }^{161}$ Unpaid child support can be obtained from parents by withholding income, intercepting tax refunds, placing a lien on the parent's property, suspending the parent's driver's license, seizing the parent's financial assets, and ultimately requesting a warrant for the parent's arrest to get him back into court. ${ }^{162}$ Parents who are not poor will generally be brought into compliance using one of the first four methods. ${ }^{163}$ Those methods, however, require the parent to have such assets as a job, real property, a car, or a bank account; all things that impoverished parents often do not have. ${ }^{164}$ This reduces the methods of collecting child support from impoverished individuals down to just seeking a warrant to have the parent jailed, which puts poor, noncustodial parents "at a greater risk of going to jail simply because they are poor."165

\footnotetext{
150. Id.

151. $I d$.

152. Id. at 636.

153. Id. at 637.

154. $I d$.

155. Id.

156. Id.

157. Id. at 637-38.

158. Id. at 638 .

159. Id.

160. Id.

161. Clarke, supra note 31.

162. Id.

163. See id.

164. Id.

165. Id.
} 
In the early 2000 s, a staggering $70 \%$ of all child support arrears were the debts of parents who earned $\$ 10,000$ or less annually. ${ }^{166}$ Again, these parents have to overcome great difficulty to prove they are unable to pay their child support or even receive a downward modification. Moreover, because their child support debts are unwaivable, ${ }^{167}$ those debts likely remain stagnant even today. This demonstrates that the cycle of incarceration for failure to pay child support has an enormous impact on indigent, noncustodial parents.

\section{B. African-American Fathers}

Roughly $70 \%$ of African-American children come from parents who never married, ${ }^{168}$ and roughly one in nine of them have an incarcerated parent. ${ }^{169}$ For these children born outside of marriage, their noncustodial fathers are likely not paying child support. ${ }^{170}$ Studies suggest that African-American fathers' participation in the upbringing of their children is directly related to the father's "class, education, and employment status." 171 Research shows, however, that although poor, noncustodial African-American fathers with children born outside of marriage generally are not paying child support, they are more involved with their children than non-custodial fathers of other higher income levels and of other races. ${ }^{172}$ This suggests that the lack of financial participation stems not from a lack of love, but from the adverse impacts of inequality that render these fathers less able to meet the demands of family policy. ${ }^{173}$

Young, black fathers make up a disproportionately high share of low-income, noncustodial parents. ${ }^{174}$ The rate of African-Americans in poverty is $25 \%$ in South Carolina, $38 \%$ in Minnesota, and $87 \%$ in Maine. ${ }^{175}$ The poverty rates of whites in those same states are $9 \%$,

166. Pearson, supra note 120 , at 5 .

167. Id.

168. Solangel Maldonado, Deadbeat or Deadbroke: Redefining Child Support for Poor Fathers, 39 U.C. DAvis L. REv. 991, 993 (2006).

169. Realistic Child Support Orders for Incarcerated Parents, Admin. Child. \& FAM. (June 2012), https://www.acf.hhs.gov/sites/default/files/ocse/realistic_child_sup port_orders_for_incarcerated_parents.pdf [https://perma.cc/7XM8-V7GQ] [hereinafter $A C F]$.

170. Maldonado, supra note 168, at 993.

171. Herbert Fain \& Kimberly Fain, Socio-Economic Status and Legal Factors Affecting African American Fathers, 21 Buff. J. Gender L. \& Soc. Pol'y 1, 3 (2012-13).

172. Maldonado, supra note 168, at 994-95.

173. Fain \& Fain, supra note 171, at 3.

174. Elaine Sorenson, Obligating Dads: Helping Low-Income Noncustodial Fathers Do More for their Children, URB. Inst. 1 (Mar. 1999), https://www.urban.org/sites/ default/files/publication/69661/309214-Obligating-Dads.pdf [https://perma.cc/8BFR-X XKA].

175. Poverty Rate by Race and Ethnicity, KAISER FAM. Found., https://www.kff .org/other/state-indicator/poverty-rate-by-raceethnicity/?currentTimeframe $=0 \&$ selec tedDistributions $=$ white-black\&sortModel $=\% 7 \mathrm{~B} \% 22$ colId $\% 22: \% 22$ Location $\% 22, \%$ 
$7 \%$, and $11 \%$, respectively. ${ }^{176}$ Impoverished, noncustodial parents owe the majority of accumulative child support arrears. ${ }^{177}$ Additionally, there has historically been a disparity between the incarceration rates of African-American men and white men in the United States. In 2016, 1,608 African-Americans in every 100,000 United States residents were imprisoned, while only 274 white Americans per 100,000 U.S. residents were imprisoned. ${ }^{178}$ Although the number of AfricanAmericans imprisoned has decreased yearly since 2007, the number has consistently remained significantly higher than that of white Americans. ${ }^{179}$

These issues combined-high rates of poverty, incarceration, and not paying child support-all make African American fathers easy targets for the cycle of incarceration.

\section{Criticisms of the Executive Order}

Some on the right-leaning side of the political spectrum oppose the changes made to the federal child support guidelines, pushing that the change is "dangerous" 180 and will permit parents to "avoid their financial responsibilities." 181 Opponents have vehemently battled the rule since the Obama Administration introduced it. ${ }^{182}$ These complaints are not unjustified, but appear to come from a lack of understanding of the realities of our failing child support system.

\section{A. Balancing Best Interest of the Child and a Father's Ability to Support}

Threatening noncustodial parents with incarceration for being behind in child support payments was originally intended to scare the parents into paying. ${ }^{183}$ Some would suggest that, although this is "a good public policy tool," it is not effective in practice. ${ }^{184}$ Consider a parent who is behind in child support payments due to unemployment

22sort\%22:\%22asc\%22\%7D [https://perma.cc/DRE6-HFFW] (last visited Oct. 21, 2018).

176. $I d$.

177. Pearson, supra note 120 , at 5 .

178. E. Ann Carson, Prisoners in 2016, U.S. DeP'T. Just. 8 (Aug. 7, 2018), https:// www.bjs.gov/content/pub/pdf/p16.pdf [https://perma.cc/AS4Y-WAKU].

179. See id.

180. Connor D. Wolf, House Republicans Move to Stop Dangerous Child Support Rule, Daily Caller (June 9, 2015, 4:12 PM), http://dailycaller.com/2015/06/09/houserepublicans-move-to-stop-dangerous-child-support-rule/ [https://perma.cc/MVG2-5Q $3 \mathrm{H}]$.

181. Rascoe, supra note 5.

182. See Pete Kasperowicz, GOP Hoping to Kill Obama Rule That Lets Parents Skip Child Support Payments, WASH. Examiner (June 11, 2015, 3:53 PM), http://www .washingtonexaminer.com/gop-hoping-to-kill-obama-rule-that-lets-parents-skip-childsupport-payments/article/2566072 [https://perma.cc/73GZ-ASJ2].

183. SOlOMOn-FeArs et Al., supra note 13 , at 13.

184. Id. 
and therefore faces the possibility of incarceration. The parent likely will not make payments in the face of such coercion, as they do not have money. When a parent is placed in jail for contempt, he is unable to earn wages to pay off the child support or otherwise support their children. ${ }^{185}$ The contemnor could even lose their job due to being jailed. ${ }^{186}$ Furthermore, it is not uncommon for fathers to avoid the child support enforcement system's radar by disappearing and taking on unconventional methods to earn income. ${ }^{187}$ These unconventional sources of income are often related to crime. ${ }^{188}$ This leaves the child without any financial support from their father, and eliminates their ability to sustain a relationship with them. ${ }^{189}$ Therefore, the threat of imprisonment will not, in the case of an unemployed parent or a poor parent, bring about the outcome initially desired.

Studies suggest that the delinquency of a large portion of these noncustodial parents is a result of "income levels, employment history, education levels, and a rate of institutionalization," but not from a sheer refusal to pay. ${ }^{190}$ This may be because support orders against low-income earners often do not reflect the parents' financial realities and, therefore, tend to exceed what the parents realistically can pay while maintaining their own needs. ${ }^{191}$ Rottscheit $v$. Dumler is a Wisconsin Supreme Court case reviewing an incarcerated father's denied request for a modification in his child support because the incarceration was voluntary. ${ }^{192}$ The father estimated that upon release from prison, he would owe approximately $\$ 25,000$ in child support arrears, not including interest, without the modification. ${ }^{193}$ Dumler's incarceration was a result of two separate convictions: (1) an operating a vehicle while intoxicated ("OWI") offense and (2) possession of cocaine, the former was his fifth or greater like-offense. ${ }^{194}$ While serving his time and before requesting a modification, Dumler continued making child support payments, but he could only give less than ten dollars for most months. ${ }^{195}$ In reviewing Dumler's request, the Court agreed with Dumler that " $\$ 25,000$ is a great deal of money," but it then stated that "it is not such an exorbitant or insurmountable amount that a judge would have to find it beyond Dumler's ability to pay over time."196 The Court then affirmed the denial of Dumler's requested modifica-

185. Patterson, supra note 132 , at 126.

186. $I d$.

187. $I d$.

188. Id at $126-27$.

189. Patterson, supra note 32, at 126.

190. Id. at 107.

191. Id.

192. 2003 WI 62, II1, 262 Wis.2d 292, 664 N.W.2d 525.

193. Id. at II6.

194. Id. II4.

195. Id.

196. Id. at $₫ 36$. 
tion. ${ }^{197}$ Thus, in Wisconsin, a $\$ 25,000$ child support debt-bolstered by threats of additional jail time for nonpayment-is not an insurmountable burden for a convicted felon with limited job opportunities upon release from prison.

The incarcerated father in Dumler raised an interesting point that the accumulation of his child support while he was incarcerated was "of no benefit to the child." ${ }^{198}$ Dissenting Judge Abrahamson agreed, stating that "child support orders that are beyond a noncustodial parent's ability to pay are not in the best interests of the child." ${ }^{999}$ Not only does the child not receive the money for the duration of the parent's incarceration; the child likely will not see it afterward, as significant accumulated child support debt incentivizes released parents to work jobs in which income is not reported or not work at all. ${ }^{200}$ Therefore, while reducing child support orders for incarcerated parents may undermine the goal of maintaining a standard of living for those parents' children, this effect is only temporary. ${ }^{201}$ In fact, failure to allow modification "will undermine this goal in both the short term and the long term." 202

\section{B. Tax Payers Picking Up the Slack}

Some believe that cutting incarcerated, noncustodial parents slack in child support while imprisoned will "undercut the 1996 Welfare Reform Act," which encouraged the collection of child support payments from fathers to mitigate the taxpayers' burden. ${ }^{203}$ Studies suggest, however, that manageable child support payments and reduced accumulated debt motivates compliance with paying those obligations. ${ }^{204}$

In a Colorado study conducted by the Center for Policy Research, two groups of parents, disabled and formerly incarcerated, participated in a debt compromise program. ${ }^{205}$ The program entailed developing customized payment plans for the noncustodial parents and creating alternatives to payment when payment was not possible. ${ }^{206}$ Compliance with the program resulted in reductions in the parents'

197. Id. at 9149 .

198. Id. at $\mathbb{I I 3 5 .}$

199. Id. at II65 (Abrahamson, J., dissenting).

200. Clarke, supra note 31.

201. Rottscheit, WI 62, II62-65.

202. Id.

203. Eli Hager, For Men in Prison, Child Support Becomes a Crushing Debt, MarShall Project (Oct. 18, 2015, 5:00 PM), https://www.themarshallproject.org/2015/10/ 18/for-men-in-prison-child-support-becomes-a-crushing-debt [https://perma.cc/4X9L7WE6].

204. Id.

205. Jessica Pearson, Lanae Davis \& Nancy Theonnes, Colorado Compromise and Cooperation: Project Evaluation Final Report, CTR. FOR POL'y REs. 7-8 (2012), http:// centerforpolicyresearch.org/wp-content/uploads/ColoradoCompromiseCooperation .pdf [https://perma.cc/ZB2E-QGD7].

206. Id. 
arrears awarded over the course of a twelve-month schedule. ${ }^{207}$ Out of 166 formerly-incarcerated participants, $45 \%$ fully complied with the terms of the program and, therefore, had their child support debts forgiven. ${ }^{208}$ Although full compliance with the program was lower in the formerly-incarcerated parent group than the disabled parent group $-45 \%$ and $73 \%$, respectively-the formerly-incarcerated parent group paid higher monthly payments than the disabled parent group. ${ }^{209}$

There will always be noncustodial parents who just refuse to meet child support obligations, but this study proves that more parents are willing to pay when the required payments are realistic in light of their situations. Therefore, if incarcerated parents are not overloaded with child support debt upon release and can secure child support orders that reflect their actual ability to pay, tax-payers may receive a break as these parents will be more likely to pay and less likely to dodge their obligations.

\section{Potential Positive Effects of the Order}

The ultimate goal of President Obama's executive order is to "increase regular child support payments to families" 210 by eliminating the daunting, unrealistic arrearages that loom over these parents. Large child support arrearages result in lower employment and less support paid. ${ }^{211}$ By providing incarcerated parents the ability to maintain manageable child support arrears, the executive order encourages continued payment of child support upon release from incarceration. Not only does the order seek to encourage payment, but it is also expected to reduce prison populations and decrease the likelihood that noncustodial parents will go to jail for failure to make payments. ${ }^{212}$

Substantial accumulation of child support arrears discourages noncustodial parents from being present in their children's lives. ${ }^{213}$ The presence of both parents is "emotionally, psychologically, and socially beneficial" to children. ${ }^{214}$ Since it is generally fathers who are the noncustodial parents of their children, it stands to reason that fathers are generally the ones most susceptible to falling into massive child support debt and becoming unavailable to their children. Children with present fathers experience better educational outcomes, more emo-

207. Id.

208. Id. at 27.

209. Id. at 28.

210. Cohen, supra note 5.

211. Id.

212. Rascoe, supra note 5.

213. ACF, supra note 169 at 1.

214. $I d$. 
tional security, better social connections, and more independence. ${ }^{215}$ The executive order can help noncustodial fathers who have been released from incarceration attain these outcomes for children by removing the financial incentive for these fathers to disappear in fear that they will be arrested for nonpayment.

\section{Conclusion}

Prior to President Obama's executive order, states had full discretion in determining whether a noncustodial parent's incarceration was voluntary or involuntary, thereby giving them complete discretion in discerning whether the parent was entitled to a modification to their child support order. Although some states recognized that allowing the parent to accumulate tens of thousands of dollars in debt did not help to support the reentry of these parents into society, other states regarded the issue as a decision made by the parent through their actions. Once released from prison, those who could not manage to obtain a modification also could not manage to pay down their debt. The process of civil contempt for failure to pay encouraged those who could not get out of debt to avoid employment or engage in underground, off-the-radar work.

Instead of seeking to punish these parents for being unable to pay their child support, President Obama sought to address the problem and issued an executive order prohibiting courts from labeling incarceration as involuntary. Although the order is still fairly new, there are high hopes that it will encourage noncustodial parents to pay child support, rejoin formerly incarcerated parents with their children, and help break the cycle of incarceration that plagues low-income, noncustodial parents.

The executive order, with its fate in the hands of the Republican Trump Administration, is now vulnerable to being overturned. But, if this administration hopes to make progress with child support payments, it will keep the executive order in place. This order will allow incarcerated parents a better chance to modify their support orders, which will provide them with a real chance to start paying off their child support debt upon release. This helps both the parent and the child as it promotes relationships between the two. A parent is more likely to build a relationship with the child when the parent is not avoiding unaffordable child support arreages. If courts want to provide parents and children with even more support, then courts could choose to suspend the accumulation of child support debt entirely while the parent is incarcerated instead of merely providing a down-

215. Jeffrey Rosenberg \& W. Bradford Wilcox, The Importance of Fathers in the Healthy Development of Children, Child Abuse and Neglect User Manual SeRies, Dep't Health \& Human Servs. 12-13 (2006), https://www.childwelfare.gov/ pubPDFs/fatherhood.pdf [https://perma.cc/DD5G-953A] (last visited Oct. 21, 2018). 
ward modification. Since a parent generally cannot pay any child support while incarcerated, allowing the order to accumulate during confinement does not provide the child with any support.

In 2015, Texas amended Section 154.068 of the Texas Family Code. ${ }^{216}$ The amendment restricts courts from imputing income equal to a minimum wage forty-hour work-week on parents who are serving more than ninety days of incarceration. ${ }^{217}$ As more legislatures and courts become aware of the problems with child support enforcement, and likewise more aware of solutions to these problems, there is hope that noncustodial parents will receive more help, children will receive more love and support, and America will see real change.

216. See Exempt Eligible Parents Who Have Been Incarcerated For At Least 90 Days From Accumulating Child Support Debt, Tex. Crim. Just. CoAlition, https:// www.texascjc.org/exempt-eligible-parents-who-have-been-incarcerated-least-90-daysaccumulating-child-support-debt [https://perma.cc/YJ7G-PT9V] (last visited Oct. 21, 2018).

217. Tex. Fam. Code Ann. $§ 154.068$ (West Supp. 2018). 
